\title{
The Development of Industry as a Condition for the Development of Urban Planning and Architecture on the Example of an Industrial Site in Podbrezova
}

\author{
BELLAKOVA Eva ${ }^{1, a^{*}}$ \\ ${ }^{1}$ Faculty of Architecture STU, Namestie Slobody 19, 812 45, Bratislava 1, Slovakia \\ aeva.bellakova@gmail.com
}

Keywords: Industrial area, urban development.

\begin{abstract}
Adequate natural conditions, including good raw materials and energy base, are prerequisites for a development of industrial production. The industrial production in these areas causes a creation of a settlement dependent on industrial activities. In this way the development of the industry results into the social and cultural development of regions and settlements. This simple scheme of regional development is accompanied by the construction of technical, industrial and ultimately residential and public buildings. In particular, a good production potentiality is the common characteristic of the construction development.

The impact of the industrial production on architecture and urban development is indisputable. The paper will present this dependence on the example of the most important iron producer in the former Kingdom of Hungary- Hronec complex. Ironworks in Podbrezova became the most important industrial site of the Hronec complex in the late 19th century and, today, it ranks among the European leaders in its field.

The industrial area of Podbrezova has determined the urban development throughout its history. The urban and architectural development of Podbrezova in the second half of the 20th century fluently followed up the development of the previous period. As then, production facilities has remained subject to the changing conditions of the production and the surrounding urbanism has been determined in response to these changes. Podbrezova's spatial layout represents complementarity between the current production requirements and demands of the population. The ability to adapt to changing conditions has guaranteed that Podbrezova is still a viable and workable urban structure.
\end{abstract}

\section{Introduction}

Ironworks in Podbrezova is the only continuously functioning industrial area of the metallurgical production in Slovakia with the gradual urban development, reflecting the needs of industry. The urban area of the tree local municipalities- Podbrezova, Valaska and Hronec forms a single urban unit, depended on industrial development and determined by geographical conditions. Despite the fact that there are three different cadastral territories, their urban growth and development is inextricably linked.

A new big state owned metallurgical complex- Hronec complex- was established in the area of Pohronie in the second half of the 18th century. The ironworks in Hronec gradually developed into the centre of the state iron-making enterprise. The iron-making complex of Hronec was the most outstanding, largest and most modern manufacture of its kind while ranking among the most important producers of iron in the Kingdom of Hungary [1]. Hronec enjoyed political, cultural and social influence in Podbrezova until the mid-20th century. In the second half of the 20th century, the impact of ironworks in Hronec was completely replaced by influence of ironworks in Podbrezova. Podbrezova ironworks prompted the further development of the entire community of Podbrezova and Valaska.

This study deals with urban development of Podbrezova and Valaska in the second half of the 20th century, which are the examples of urban development determined by the industrial area. The 
aim of this study is to emphasise and demonstrate the inevitable relationship between the urban development and the prosperity of local industry.

\section{The urban development of Podbrezova until the mid-twentieth century}

Podbrezova was founded as a part of the village of Lopej in the mid-19th century. Over decades, the environment developed as an industrial settlement of local ironworks and as a part of the complex of Hronec [2]. The ironworks in Podbrezova were established in 1840 and located near the river Hron. Construction of the factory and surrounding residential buildings respected the topography of the terrain while taking into account the location of the village in a narrow river valley at the foot of the hill Brezova. The settlement thus expanded in the direction of the Hron river, alongside the existing road. At that time, several settlement in Valaska, Lopej and Stiavnicka already existed in the neighbourhood of Podbrezova ironworks. The development of these settlements gradually began to be associated with the development of Podbrezova.

The processing of iron was based on natural sources of energy, water, wind and charcoal. As a result, the respective factories were geographically dispersed. Establishing new ironworks in Podbrezova was a first step in gradual cancellation of the territorial production scattering that was typical for manufacturing methods of production. About 50 to $60 \%$ of Hronec complex production was manufactured in Podbrezova already in the 1850s. Thus, Podbrezova gradually gained a dominant position within Hronec complex [3].

In the period between 1840 and 1950, Podbrezova undergone a significant development, while the importance of the factory was growing. The industrial area of ironworks was extended and modernized by technological changes and expansions of production. In the 1850 s, residential buildings, stables for horses and inn were constructed close to the service facilities [2]. The surrounding settlement was extended to the north and east of the industrial site. The urban area was thus shaped in the east-west direction along the river Hron and road (today road I/66). Then, new streets with the new residential buildings were built for employees and management of the factory. Local school, kindergarten and church were built later as well.

In the 1940s, the construction of the town extended southwards. During the war, Hermann Goring Werke weapons production, a German corporation, became new owner of the plant. A new residential district, called Hitler quarter, was constructed. The quarter consisted of three-storey blocks of flats with a gable roof for special employees. The building of the State junior school that was constructed alongside the residential district in 1950, was designed by architect Bohuslav Fuchs, one of the best Czechoslovak architects of the 20th century [4].

\section{Urban development of Podbrezova and Valaska after 1950}

The urban conglomeration of Valaska and Podbrezova today consists of several parts. Podbrezova as the local part of the village Lopej and then as a new municipality has continued to develop demographically, socially and architecturally as part of the local ironworks. This development in the second half of the 20th century extended into the neighbouring village Valaska. The municipality of Podbrezova was established in 1953 and, today, it consists of six local partsPodbrezova, Lopej, Vajskova, Skalica, Stiavnicka, Chvatimech [2]. Lopej, Vajskova and Stiavnicka are the settlements of family houses incurred prior to the construction of factories in Podbrezova. However, the factory influenced them so their further development depended on its prosperity. The establishment of Chavatimech and Skalica was directly related to the construction of ironworks in Podbrezova.

The factory in Podbrezova, in the second half of the 20th century, was gradually modernized, rebuilt and the industrial site was extended. The prosperity of the factory has been reflected in the surrounding urban expansion, including the establishment of entirely new urban structures. The architectonic and functional centre of Podbrezova has become the main square (Sladkovicova street) 
at the entrance to the factory. During the second half of the 20th century, Valaska became a suburb of Podbrezova.

The urban development of Podbrezova and Valaska since the mid-twentieth century can be divided into three groups: the extension of the industrial area, the development of the surrounding areas and the establishment of the new urban structures. The industrial area of Podbrezova, now called Zeleziarne Podbrezova old plant, extended alongside the existing industrial area in narrow valley of the river Hron and the arterial road in east-west direction. The residential districts of Podbrezova extended in the north-west direction to places of the flat terrain. Thus, new roads are perpendicular to the traffic artery. Valaska experienced rapid urban growth and increase of population in the second half of the 20th century (Valaska had 1929 inhabitants in 1950 and 3862 inhabitants in 2001 [5]. Podbrezova had 3089 inhabitants in 1950 and 4295 inhabitants in 2001 [2]). In the 1970s, the ironworks was expanded by a new plant in Piesok, now called Zeleziarne Podbrezova new plant. The new suburbia, called Sidlisko, was established to the south of the old village. The area of the original village Valaska was expanded with the development of the plant too.

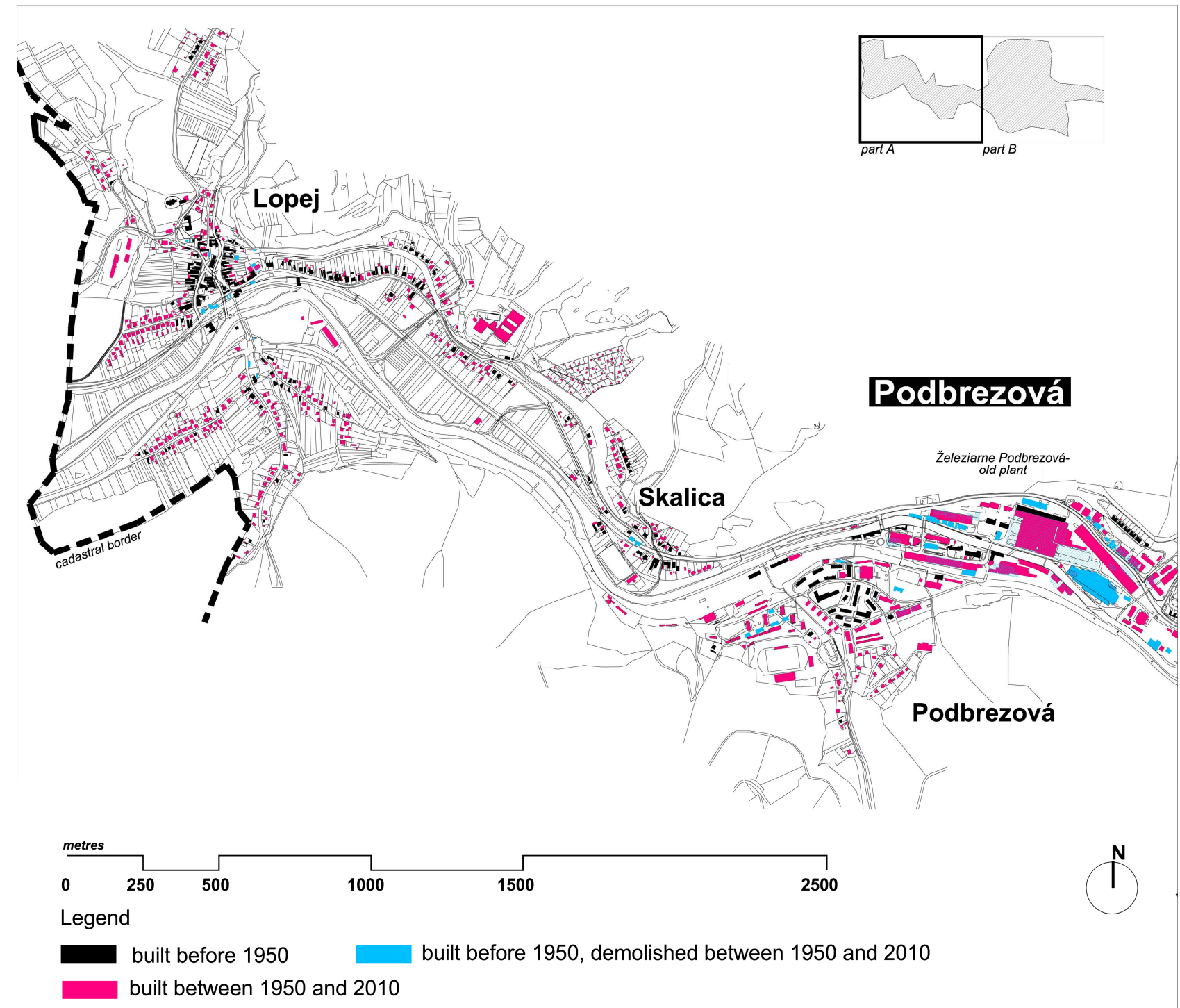

Fig. 1. The urban development of Podbrezova and Valaska- part A

In the post-war period, the Podbrezova ironworks was the only metallurgical enterprise in Slovakia, thus the government supported its development and the ironworks became one of the major strategic enterprises of Czechoslovakia. Therefore, the renovation and expansion of the ironworks began. Since the mid-20th century, the factory was constantly modernized, rebuilt and 
gradually changed its appearance. The family houses near factory were demolished and replaced by the industrial area because of narrow river valley. In the 1950s, a new open-hearth steel mill and generating station were built in front of a modernized rolling mill hall. Both new industrial halls have steel skeleton and masonry infill, that allow to change the technology equipment without major problems. At that time, two new mills were built in Czechoslovakia, therefore the Podbrezova ironworks were predominantly focused on the production of open-hearth steel mill as so as on improving ingots quality. The construction of a steel stripping bay in 1967 represented an important technical improvement [3].

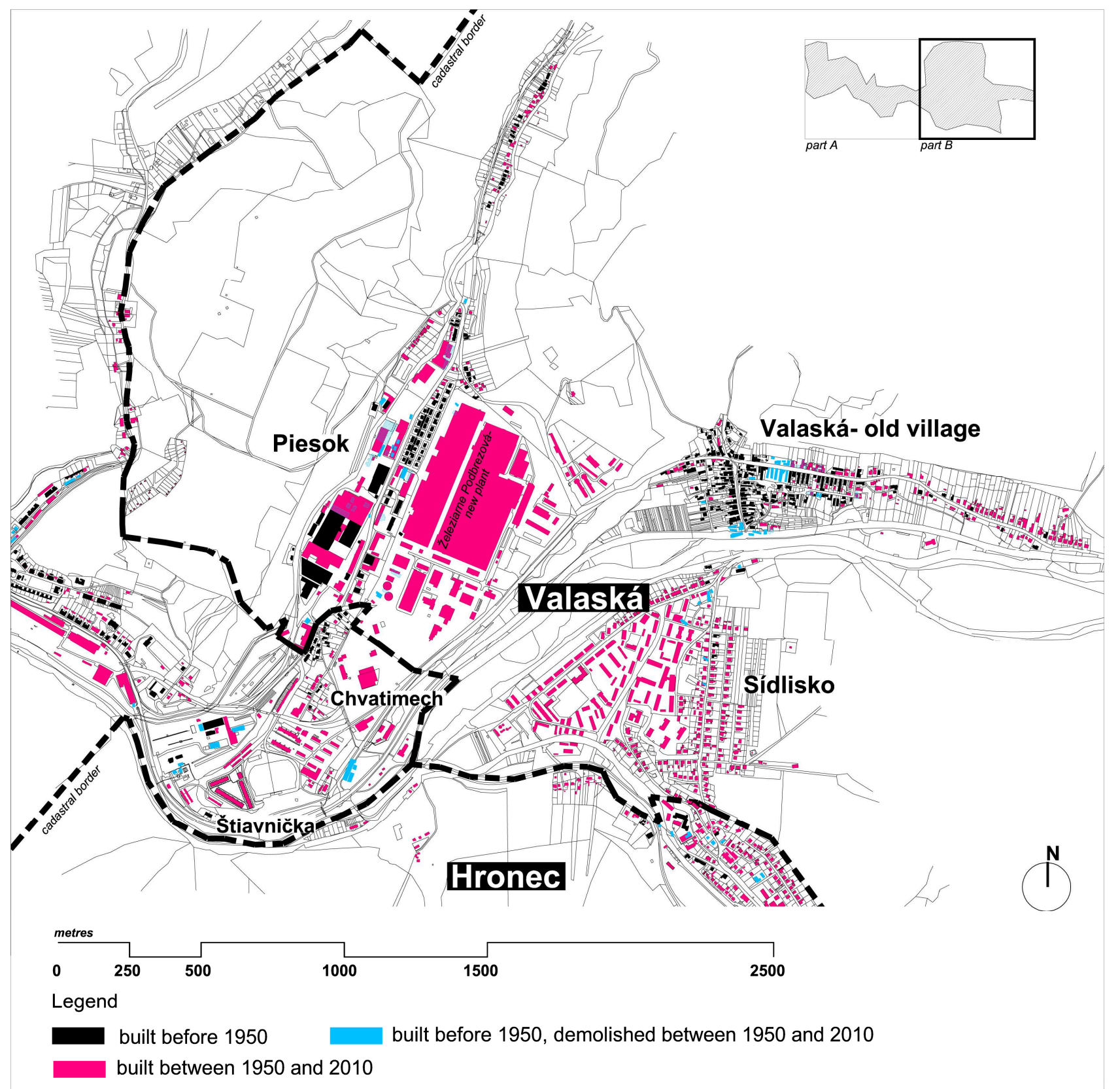

Fig. 2. The urban development of Podbrezova and Valaska- part B

The increasing number of factory employees caused the construction of new housing in Podbrezova and Valaska. The construction of residential district Kolkaren in the 1950s, continued in urban concepts of existing buildings (the Hitler district). New 12-storey residential tower blocks at Supkova quarter, a new football stadium and swimming pool was constructed in the 1960s and 1970s. Since the narrow river valley did not provide enough space for the construction of a large housing estate in Podbrezova, its construction was planned in Valaska. Thus, a new suburb Sidlisko that was built in the late 1950s, was designed by the Slovak architect Martin Kusy [6]. Sidlisko is 
lying south of the historic village and is bounded by the river Hron and railroad tracks. The construction of this suburb solved the housing problem of the factory workers. Along the northsouth compositional axis of the suburb (Trieda duklianskych hrdinov street) is a line of 4-storey housing blocks, in the middle of which is the civic centre- Namestie 1. maja. The square is surrounded by buildings of public amenities and dominated by a town hall [5].

In the 1970s, the old rolling mill that represented the outdated metallurgical production, was unfit for new technological processes. Therefore, the old rolling mill was replaced by a new hall in 1982. The construction of a new steel mill in Podbrezova was associated with a specialization in manufacturing of seamless and precise drawn pipes. Already during the 1960s, a plant management realized that production must focus on scarce production of Czechoslovakia. Therefore, the construction of Zeleziarne Podbrezova new plant in Valaska-Piesok was approved. The construction took place from the 1970s until 1993. The successful completion of a new pipes rolling mill, a new pipes drawing mill and a new electric steel shop made the Podbrezova ironworks a self-supporting company in steel. In all activities connected with the production expansion, the Podbrezova ironworks have always improved the operations and modernized machines and equipments [3].

The development of the ironworks is also reflected in the development of local parts of Podbrezova. In local part of Lopej, the housing estate expanded on the south bank of river Hron, alongside the road perpendicular to the main traffic artery. The building of the Vocational School of Metallurgy was constructed there in 1988. Today it is the Private Secondary Technical School of Metallurgy Zeleziarne Podbrezova and the Private High School Zeleziarne Podbrezova [3]. In local parts of Stiavnička and Chvatimech, that fill the narrow river valley between Podbrezova and Valaska, was built new housing estate, kindergarten and elementary school with a football field.

\section{Conclusion}

Since the mid-20th century, a significant urban, demographic and social development in Podbrezova and the surrounding region has been conditioned by the development of the factory. The Podbrezova ironworks have been continually modernized and adapted according to the new production needs to endure in a competitive environment. Thanks to the thriving company, new jobs outside needs of factory was initiated. In the course of time, the factory formed its environment in a way which provided for that, today, Podbrezova and Valaska meet all the requirements not only of modern industry but also of workable urban structure. The urban development of Podbrezova and Valaska demonstrates that the prosperity of the factory is able to encourage the development of existing urban structures and to initiate the establishment of new urban structures. The urban conglomeration of Podbrezova and Valaska confirms that industry is the main determinant of the urban development.

\section{References}

[1] M. Sarudyova, Topografia zeleziarni na Slovensku v 19. storoci, Vychodoslovenske vydavatelstvo, Kosice, 1989.

[2] J. Alberty et al., Podbrezova, Tristar Magic, Slovenska Lupca, 2008.

[3] T. Turcan et al., Zeleziarne Podbrezova 170 rocne, Podbrezova, Kosice, 2010.

[4] M. Dulla, H. Moravcikova, Architektura Slovenska v 20. storoci, Slovart, Bratislava, 2002.

[5] J. Alberty et al., Valaska- monografia obce, Studio Harmony, Banska Bystrica, 2002.

[6] E. Hruska, Vyvoj stavby miest, Veda, Bratislava, 1961. 